\title{
Livsformer og livskvalitet i Grønland: Et indblik i sammenhængen og den potentielle udvikling
}

Naja Carina Steenholdt ${ }^{1}$, ph.d.-studerende ved Aalborg Universitet og Ilisimatusarfik

I denne artikel undersøges det noermere, hvordan livsformer og livskvalitet hoenger sammen $i$ Grønland set $i$ et samfundsvidenskabeligt perspektiv. Artiklen forholder sig endvidere til, hvordan dette hoenger sammen med landets udvikling mod selvstcendighed. Livs$k$ valitet og forestillingen om det gode liv hører til det kulturelle og vardiladede i en livsform. Det er med andre ord en forestilling om, hvordan tingene bør, skal eller kan vore, for at vi kan føle, at livet er godt. Men det betyder også noget, hvor man bor. Det er en klassisk opfattelse, at man har en vasentligt anderledes livsform i en by kontra en bygd, og har forskellige vardier og holdninger til, hvad livskvalitet kan vare. Artiklen, som er et indledende studie på området, vil på baggrund af resultater fra et sociologisk feltarbejde i Sydgrønland i 2018, samt gennem en analyse og diskussion af livskvalitet og etnologen Thomas Højrups livsformsanalyse, stille spørgsmålene: Hvordan honger livsformer og livskvalitet sammen i Grønland? Og er der en sammenhoeng med den nuvarende udvikling mod selvstcendighed? Artiklen fremfører, at livsformer og livskvalitet $i$ høj grad er forbundet med relationer til familie, natur og arbejde, men at det grønlandske folks evne til at tilpasse sig også spiller en rolle i forholdet mellem livsformer og livskvalitet.

\section{Indledning}

Hvordan livet leves, påvirker, sammen med livsbetingelserne, livets kvalitet. Det virker som en temmelig banal påstand, men når dette skal forstås gennem et helt samfunds optik, bliver det anderledes kompliceret. En livsform kan ifølge etnologen Thomas Højrup betegnes, som det der sammenfatter distinkte måder at leve på, på en måde så de kan identificeres og adskilles fra hinanden i klynger (Højrup 1983). Livskvalitet er den subjektive

\footnotetext{
${ }^{1}$ Naja Carina Steenholdt er dobbeltindskrevet ph.d.-studerende ved Aalborg Universitet og Ilisimatusarfik siden november 2017. Hun forsker i livskvalitet og sociale indikatorer i Grønland. Naja Carina er herudover affilieret medlem af forskningsgruppen Centre for Innovation and Research in Culture and Living in the Arctic (CIRCLA) i AAU.
} 
evaluering af den samlede livsoplevelse på et givent tidspunkt (Veenhoven 2014). Befolkningsstudier såsom Survey of Living Conditions in the Arctic (SLiCA) (Poppel et.al 2007) og Arctic Social Indicators (Larsen et. al 2010) viser, at der er forskellige livsformer i Grønland og at livskvalitet anskues forskelligt fra sted til sted. Dette er ikke unikt for landet; sådan er det alle steder i verden. Kontrasten - og i nogle henseender opgøret mellem den rurale og urbane livsform er heller ikke enestående for Grønland. Der er dog grund til at tage et nærmere kig på forholdet mellem livsformer og livskvalitet. Den grønlandske befolkning står nemlig over for nogle potentielt afgørende ændringer i samfundet. Særligt debatten om selvstændighed har fyldt i medier og i politisk regi. Hvordan en eventuel selvstændighed vil påvirke livsformerne i Grønland og hvordan det vil påvirke livskvaliteten, kan ingen med sikkerhed vide. Men ved at forstå sammenhængen mellem livsformer og livskvalitet i det grønlandske samfund, er det måske lettere at forstå, hvad der er vigtigt for det grønlandske folk, og hvad der er på spil, når store forandringer står for døren.

\section{Baggrund}

Det grønlandske samfund har i løbet af det seneste århundrede undergået store samfundsmæssige forandringer. I 1979 fik landet officielt hjemmestyre. 30 år senere på samme dag blev dette ændret til selvstyre, og den grønlandske befolkning kom dermed et stort skridt nærmere selvstændighed (Skydsbjerg 1999). Landets økonomi er i dag stadig afhængig af det danske bloktilskud, som udgør lidt over halvdelen af Landskassens indtægter (se Nauja Biancos artikel om Grønlands økonomi og erhverv i dette temanummer). Hertil er der hele debatten om udvinding af råstoffer og åbningen af nordvestpassagen, som vil få økonomisk og strategisk betydning for mange lande, ud over Grønland. Selvom debatten om selvstændighed, miner og søfartsruter uden tvivl er de mest omdiskuterede udviklingspotentialer i Arktis, så er der et andet udviklingspotentiale, der i høj grad hænger sammen med selvstændighedsprocessen; nemlig udviklingen af menneskene i landet. Den grønlandske befolkning har en væsentlig rolle i selvstændighedsprocessen, fordi det er dem, der skal stemme om beslutningen om selvstændighed, og fordi det er dem, der skal leve med udfaldet af beslutningen. Parallelt med det stigende ønske om selvstændighed, rapporteres der om forværring af folkesundheden på visse områder, heriblandt selvvurderet helbred, samt en øget social ulighed (Larsen et.al 2019). Samtidig bliver levevilkårene gradvist bedre i byerne, så flere flytter fra bygd til by; især til Nuuk. 


\title{
Livsformer og livskvalitet
}

\section{Livsformer}

Livsformer er, ifølge Højrups livsformsanalyse, de grupperinger der skabes af samfundets struktur og produktionsmåde ${ }^{2}$ :

\begin{abstract}
"Man må forsøge at skyde sig ind på det samlede billede, der tegner sig af en gruppe menneskers liv, når man kender deres daglige gøremål, ugens gang og aktiviteterne året rundt. Man må vide, hvorledes folkenes livsforløb former sig, hvorledes familiernes daglige rutine aendrer sig med alderen, og man må kende til arbejdslivet, fritidsinteresserne, omgangskreds og samvarsformer. Kan der tegnes et sammenhongende billede af livet, som det ud fra disse synsvinkler former sig fra opvakst til alderdom, så vil denne helhed betegnes som en livsform." (Højrup 1989).
\end{abstract}

Hvis man bor i Qeqertarsuaq, vil livet derfor, strengt forenklet, være betinget af de livsbetingelser der er der. Betingelser, som man enten former livet efter, eller bryder op med og flytter væk. Sidstnævnte er dog ifølge Højrup ikke noget, man bare gør, for er man først bærer af én livsform, så ændres den ikke så nemt. Men at flytte sig og tilpasse sig, er ikke ubekendt for den grønlandske befolkning, der har flyttet sig fra sted til sted gennem årtusinder, og det er måske her forklaringspotentialet i Højrups teori bliver udfordret, når vi skal prøve at forstå den specifikke grønlandske virkelighed. Dette vil artiklen forsøge at udfolde i diskussionsafsnittet.

I livsformsanalysen deles livsformer op i en rural og urban livsform ${ }^{3}$, hvilket her sammenlignes med livsformerne i en grønlandsk bygd kontra bylivsformen i Nuuk. Ifølge Højrup, er den rurale og den urbane livsform overvejende modsætninger, og et individ der er bærer af én livsform, kan ikke samtidigt være bærer af flere livsformer. Dette forklares med livsformens ideologiske karakter. En livsform udgør nemlig mere end blot, hvor man bor, eller hvad man laver på arbejde og i fritiden.

\section{By-bygd forholdet}

Livsformsanalysen differentierer mellem land og by bl.a. i "forskellen mellem enkel vareproduktion - familiebrug - og kapitalistisk produktion - industri" (Højrup 1983, 50).

\footnotetext{
${ }^{2}$ Produktionsmåde-begrebet knytter sig til Højrups marxistisk inspirerede ide om samfundets økonomiske struktur, som indebærer to produktionssystemer, som er med til at definere livsformernes grundlag. Der er den enkle vareproduktion og den kapitalistiske produktionsmåde. Groft forenklet kan man sige, at den enkle vareproduktion er dem der ejer og forestår en (vare)produktion, med andre ord dem der er selvstændige og som producerer en vare/ydelse, og den kapitalistiske produktionsmåde er dem der ikke ejer en produktion, men som så at sige, sælger deres arbejdskraft til den enkle vareproduktion.

${ }^{3}$ Ud over opdelingen mellem den rurale og urbane livsform, beskriver Højrup de tre arketypiske livsformer: den selvstændige livsform, lønmodtagerlivsformen og karrierelivsformen. Karakteristikken af disse livsformer er særligt centreret om arbejdets betydning for livsformen. Af pladsmæssige hensyn udelades det at komme nærmere ind på dette.
} 
Groft forenklet betyder det, at bæreren af en landlig livsform typisk er selvstændig og selv opretholder sin livsform, hvorimod bæreren af en livsform i byen typisk er lønmodtager og således afhængig af andre for at opretholde livsformen. Det betyder ikke, at alle der bor i byen er lønmodtagere, og at alle der bor på landet er selvstændige, men at der er tale om en rural og en urban identitet. I Grønland karakteriseres et sted som en by, når der er mere end 500 indbyggere (Poppel 2015; Hendriksen 2013). I denne sammenhæng er det dog - i lighed med livsformsanalysens syn på by-land-forholdet - ikke antallet af indbyggere, men den kulturelle karakter af stedet der bestemmer, om det er en by eller bygd.

\section{Den urbane livsform}

I livsformsteorien har mennesker der bor i byen en væsentlig anderledes livsform end mennesker, der lever uden for byen. Tempoet er lidt hurtigere i byerne, og så er man som individ mere anonym i byen, end man er ude på landet. Man kender ikke nødvendigvis dem, man passerer på sin vej, om det er på gaden, i supermarkedet eller hvor man ellers opholder sig uden for hjemmet. Man bruger også mere tid på transport, cafeture, biograf/teaterbesøg og arbejde, end man bruger i hjemmet. I byen er der nem adgang til det meste og til regelmæssig offentlig transport, så man kan komme fra A til $\mathrm{B}$ nemt og hurtigt. Adgang til naturen sker typisk igennem en konstrueret natur i parker og offentlige steder, eller i forbindelse med ferierejser- og ture.

\section{Den rurale livsform}

Den rurale livsform er på mange måder karakteriseret ved at være en modsætning til den urbane livsform. Her er tempoet langsommere, og man bruger mere tid i hjemmet end uden for hjemmet. Når man bevæger sig uden for hjemmet, er det meget sandsynligt, at man kender dem, man møder på sin vej; hos frisøren, hos den lokale købmand osv. Måltider laves i hjemmet, og øvrige aktiviteter er ofte også knyttet til enten hjemmet eller lokalområdet. Det belyses senere i artiklen, at rurale og urbane livsformer i grønlandske byer og bygder kommer til udtryk på en anderledes måde

\section{Livskvalitet}

Livskvalitet er et komplekst begreb, som kan måles på mange måder. Videnskabeligt er der flere bud på en samlet definition af livskvalitet, og der er delte meninger om, hvordan man bedst måler det. Simpelt beskrevet, handler det om, hvordan den enkelte betragter sin livskvalitet, når alt tages i betragtning. Der er en sammenhæng mellem livskvalitet og gode levevilkår, men det er svært at tale om for et helt samfund, og nogle mener ligefrem, at det er umuligt. Andersen \& Poppel kritiserer, at traditionelle studier i levevilkår ofte er baseret på en ide om, at samfundet er en homogen størrelse, som man kan sige noget generelt om (Andersen \& Poppel 2002). Vedrørende livskvalitet fremfører Veenhoven en lignende iagttagelse i Encyclopedia of Quality of Life. Han mener at, 
"[u]dtrykket "individuel livskvalitet" bruges til at angive, hvor godt en person lever. Den individuelle kvalitet afflere personers liv kan aggregeres for at opnå et tal, der afspejler den typiske livskvalitet i en kollektivitet, såsom en nation. Men begrebet gaelder ikke for sociale systemer. Man kan ikke sige, at et samfund lever godt, da samfundene ikke "lever4"." (Veenhoven 2014).

Livskvalitet er altså en individuel betragtning, hvorfor der her anvendes en definition på den subjektivt opfattede livskvalitet, som mere specifikt kan defineres som:

" [...] hvordan mennesker opfatter og bedømmer deres liv. Det er en opfattelse, der giver den subjektive bedømmelse af livsoplevelsen. Komponenterne fokuserer på den generelle tilfredshed med livet og lykke, samt tilfredshed med bestemte områder af livet, f.eks. argteskab, sociale relationer, arbejde, fritidsaktiviteter og sundhed ${ }^{5}$." (Liao 2014).

\section{Metode}

Denne artikel vil over de følgende to afsnit diskutere, hvordan livsformer og livskvalitet hænger sammen. Diskussionen vil danne grundlag for en analyse af, hvordan dette hænger sammen med den foranstående udvikling hen imod selvstændighed i Grønland. I analysen af livsformer er der taget udgangspunkt i centrale begreber fra Thomas Højrups livsformsteori. Gennemgangen af teorien er ikke udtømmende, men har fokus på især begreberne den urbane og rurale livsform. Desuden er der taget udgangspunkt i Liaos definition af subjektiv livskvalitet (Liao 2014). Herudover anvendes data fra mit feltarbejde i april 2018 i de sydgrønlandske byer og bygder: Qaqortoq, Nanortalik, Narsarsuaq og Qassiarsuk. Jeg udførte 16 semi-strukturerede interviews med kvinder og mænd mellem 18-65 år, som blev fundet via snowball-metode; dvs. ved at spørge person til person om de kendte nogen, der kunne være interesserede i at deltage. Herudover anvendtes convenience-sampling (Creswell 2013), som kort beskrevet går ud på, at jeg - grundet den korte periode jeg var på stederne - gik efter personer, der var nemme at få fat i: F.eks. via Facebook-grupper samt ved at spørge folk, jeg mødte på gaden eller i supermarkedet. I undersøgelsen deltog 11 kvinder og 5 mænd $^{6}: 7$ personer mellem 18-30 år, 7 personer mellem 31-40 år samt 2 personer mellem 41-65 år. Interviewpersonerne blev stillet åbne holdningsspørgsmål samt spørgsmål om baggrundsvariable ud fra en interview-guide (figur 1).

\footnotetext{
${ }^{4}$ Egen oversættelse

${ }^{5}$ Egen oversættelse

${ }^{6}$ Resultaterne for mænd og kvinder var ikke meget afvigende fra hinanden, men det var væsentligt sværere at få mænd til at henvende sig for at deltage i undersøgelsen, hvilket jeg var forberedt på. Det kan naturligvis have påvirket resultatet, hvilket der her skal tages forbehold for.
} 


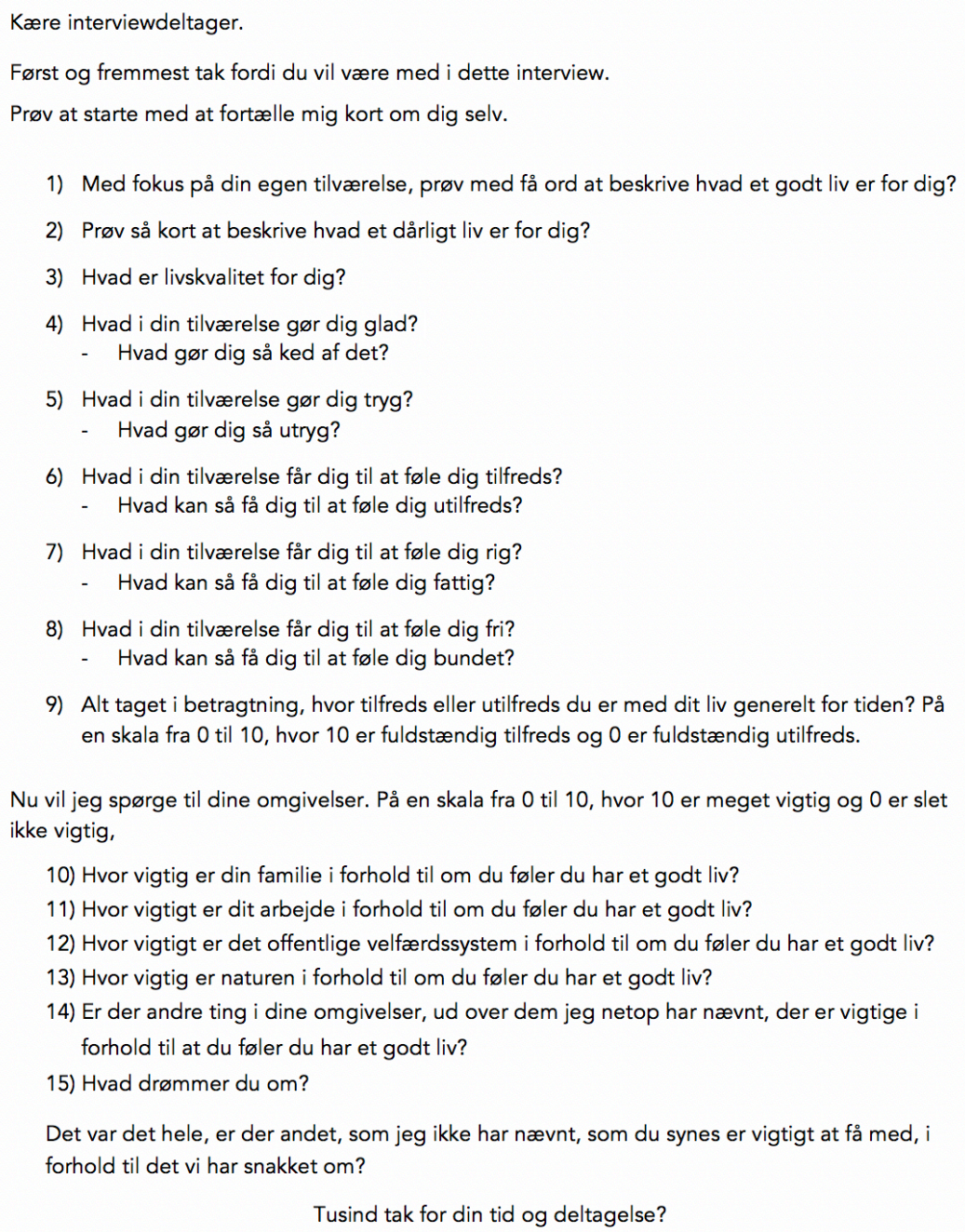

9) Alt taget $i$ betragtning, hvor tilfreds eller utilfreds du er med dit liv generelt for tiden? På en skala fra 0 til 10, hvor 10 er fuldstændig tilfreds og 0 er fuldstændig utilfreds.

Nu vil jeg spørge til dine omgivelser. På en skala fra 0 til 10, hvor 10 er meget vigtig og 0 er slet ikke vigtig,

10) Hvor vigtig er din familie i forhold til om du føler du har et godt liv?

11) Hvor vigtigt er dit arbejde i forhold til om du føler du har et godt liv?

12) Hvor vigtigt er det offentlige velfærdssystem i forhold til om du føler du har et godt liv?

13) Hvor vigtig er naturen i forhold til om du føler du har et godt liv?

14) Er der andre ting i dine omgivelser, ud over dem jeg netop har nævnt, der er vigtige $i$ forhold til at du føler du har et godt liv?

15) Hvad drømmer du om?

Det var det hele, er der andet, som jeg ikke har nævnt, som du synes er vigtigt at få med, i forhold til det vi har snakket om?

Tusind tak for din tid og deltagelse?

Figur 1: Anvendt interviewguide

Formålet med spørgsmålene var - udover at få interviewpersonen til at reflektere over, hvad et godt liv er - at få dem til at vurdere deres egen samlede livsoplevelse bl.a. ud fra en række spørgsmål, der opstiller modsætningspar. I interviewet blev informationer om alder, civilstatus, uddannelse, beskæftigelse samt geografiske og kulturelle tilhørsforhold indsamlet for at indhente viden om den pågældendes livsform. Der er anvendt kontekstanalyse til artiklens empiriske materiale, som primært findes blandt artikler, publikationer og statistikker, der vedrører livsformer og livskvalitet i Grønland, samt nordiske lande i et par perspektiverende analyser.

\section{Livsformer i Grønland}

Grønland er et land med vidt forskellige og kontrastfyldte kulturer og livsformer. Som i mange andre samfund er der forskellige syn på livet fra by til bygd og fra person til per- 
son. Det kan være vanskeligt at udpege generelle træk, men der er tendenser, som karakteriserer livsformerne i de forskellige regioner, og som adskiller dem fra hinanden. For eksempel når man ser på folks arbejdsliv. I 2016 var der flere registrerede enkeltmandsvirksomheder i den nordligste kommune, Qaasuitsup Kommunea, end der var i hovedstadens kommune, Sermersooq, til trods for, at der på tidspunktet var omtrent 30\% flere indbyggere i Sermersooq end i Qaasuuitsup Kommunea (Grønlands Statistisk 2016b, Grønlands Statistik 2016c). Dette indikerer, at der er flere med en selvstændig livsform i den nordlige region, end der $\mathrm{i}$ hovedstaden. For at blive klogere på livsformer generelt $\mathrm{i}$ landet kan man se på graden af forsyning og beskæftigelse i de forskellige regioner.

\section{Vestgrønland nord for Sisimiut}

I Nordvestgrønland er der lav forsyningsgrad ${ }^{7}$ sammenlignet med andre steder i Vestgrønland (Hendriksen, 2013), men her er store forekomster af fisk og fangstdyr. Dette er formentlig en medvirkende årsag til, at mange er selvstændige eller arbejder i selvforsynende erhverv, f.eks. inden for fangst og fiskeri. Faktisk flere end nogen andre steder i Grønland. I Upernavik og Uummannaq var det i 2016 henholdsvis 17\% og 21\% af beskæftigede, der arbejdede inden for fangst og fiskeri (Grønlands Statistik 2016b; Grønlands Statistik, 2016c).

\section{Vestgrønland fra Paamiut til Sisimiut}

I den midterste del af Vestgrønland er der højere forsyningsgrad på grund af længere isfri perioder, og arbejdsmarkedet er mere blandet. Der er dog stadig en del, der arbejder inden for fangst og fiskeri. Som f.eks. i Sisimiut hvor det i 2016 var ca. 8\% af de beskæftigede, der arbejdede inden for branchen (Grønlands Statistik 2016b).

\section{Syd}

I Narsaq og Qaqortoq arbejder mindre end 5\% af de beskæftigede inden for fangst og fiskeri. Mange arbejder i stedet som lønmodtagere, særligt i den offentlige sektor (Grønlands Statistik 2016b; Grønlands Statistik, 2016c). Derudover findes der et mindre antal landbrug og fårehold. Der er fast vareforsyning, når der ikke er storis, der driver ned fra nord.

$\underline{\varnothing s t}$

I Østgrønland er billedet igen anderledes. Andelen af fangere og fiskere er ligesom i Nuuk og Qaqortoq under 5\%, men beskæftigelsesgraden i byen Tasiilaq var i 2016 under 50\% (Grønlands Statistisk 2016e). Dette er væsentligt lavere end i de øvrige grønlandske byer; i Sisimiut lå den f.eks. på 65\% (Grønlands Statistik 2016a). Forsyningsgraden er lav og i

\footnotetext{
${ }^{7}$ Byer og bygder langs de grønlandske kyster er ikke fuldt selvforsynende, derfor kommer der vareforsyninger med skib eller fly fra de øvrige byer samt Danmark og udlandet. Forsyningen er større i sydvestlige byer og bygder, hvor der er længere isfri perioder på havet. I artiklen anvendes forsyningsgraden som indikator for graden af afhængighed af import og tjenester til regionen.
} 
de bosteder, hvor man ikke lever af administration af landet eller arbejder i landsdækkende institutioner for undervisning og sundhed, lever man typisk af naturens ressourcer.

Forskellene mellem landsdele afspejles også i andelen af personer, der modtager offentlig hjælp. I Tasiilaq var der i 2016 godt $20 \%$ af befolkningen i byen, der modtog offentlig hjælp (Grønlands Statistik, 2016c; Grønlands Statistik 2016d). I bygden Ittoqqortoormiit, der ligger i samme distrikt, var det ca. 13\% af befolkningen der i 2016 modtog offentlig hjælp (Grønlands Statistik 2016a). I Nuuk, som ligger i samme kommune, modtog 7\% offentlig hjælp. Det tegner således et iøjnefaldende billede af meget forskellige livsformer og livsvilkår, især mellem Øst og Vestgrønland.

Selv med denne forholdsvist overfladiske analyse af vareforsyning og beskæftigelse er det åbenlyst, at der er forskel på vilkårene mellem regionerne. Det har betydning for økonomien og for udviklingen mod selvstændighed. Ifølge Økonomisk Råds rapport fra 2018 er det en forudsætning for at styrke udsigterne til en selvbåren økonomi at få flere af dem, som er offentligt forsørgede til at komme i arbejde, samt at få flere til at uddanne sig (jf. Nauja Biancos artikel i dette temanummer).

\section{Rurale og urbane livsformer i Grønland}

I forhold til teorien om den urbane livsform, er der primært tale om urbane livsformer for mennesker, der lever i hovedstaden. Nuuk er en by, der minder om en moderne by, som man ser dem i Skandinavien: En gågade, butikker, et shoppingcenter, cafeer, restauranter, biograf, diskoteker, svømmehal, kulturelle tilbud og offentlig transport, der kører stort set hele døgnet. Man kan både argumentere for og imod, om der er tale om en urban livsform i byerne Qaqortoq, Ilulissat og Sisimiut, som ikke helt har de samme tilbud. Der findes butikker og enkelte restauranter, og nogle af de nævnte byer har offentlig transport, men chancen for at støde ind i en man kender, er større i disse byer, end den er i Nuuk. Sammenlignet med en by i Europa, er der formentlig flere fællestræk med en landsby, men i en grønlandsk kontekst betegnes de som byer. Den rurale livsform i Grønland kendetegner livet i bygderne og i de mindre byer. Man kender mange - hvis ikke de fleste - $\mathrm{i}$ lokalområdet, og nye ansigter, som f.eks. tilflyttere og turister, opdages hurtigt i gadebilledet.

De grønlandske livsformer og kulturer praktiseres forskelligt fra region til region. I nord fermenteres der fugle under varder, og i syd koges der fårehoveder til middag. Nationaldragter og kamikker har særlige kendetegn, så man kan se på dem, hvorfra i landet de kommer. Sprogmæssigt er det også nemt for en indfødt at høre, om man er fra Uummannaq i nord, hovedstaden Nuuk, Nanortalik i syd eller Ittoqqortoormiit i øst. Der er også visse kulturelle fællestræk, som går på tværs af byer og bygder. Eksempelvis kan man hilse samt svare ja og nej via ansigtsmimik på samme måde i hele Grønland. Efternavne og navne generelt, samt det årstal man er født, er også et særligt kulturelt emne over hele Grønland (Reimer 2010; 2012). Samtalen mellem folk, uanset om man er i by eller bygd, falder ofte på, hvad man hedder til efternavn. Hvis efternavnet er genkendeligt, 
kan man forvente at blive spurgt, om man er i familie med den eller den person, og dermed sat $i$ en form for relation til spørgeren, uafhængigt af om man kender denne eller ej. Disse få eksempler favner langt fra alle kulturelle fællestræk, men de vidner om et kulturelt behov for samhørighed eller en form for social sammenhængskraft, der går på tværs af steder og livsformer.

\section{Livskvalitet i Grønland og Arktis}

I Grønland var det først lige før hjemmestyretiden i 1970'erne, at man blev interesseret i at måle levevilkår og livskvalitet i befolkningen. De første havde fokus på folkesundhed, primært målt med kvantitative metoder (From et al. 1975, Bjerregaard 1993, Grønlands Statistik 1994). I 2006 udkom Survey of Living Conditions in the Arctic (SLiCA). Det særegne ved SLiCA var udviklingen af lokale, regionale og internationale partnerskaber med de oprindelige folk, hvis levevilkår og livskvalitet skulle undersøges. Formålet var ikke mindst at sikre fokus på forestillingerne om det gode liv blandt de oprindelige folk i Arktis - herunder de grønlandske inuit. Undersøgelsen er baseret på et spørgeskema med mere end 200 spørgsmål, og resultatet blev mere end 1.000 interviews over hele Grønland (Poppel et.al 2007). Undersøgelsens emner spænder bredt, og er kategoriseret efter 6 anbefalede sociale indikatorer (uddannelse, kulturel vitalitet, skæbnekontrol, kontakt med naturen og BNP per capita) fra Arctic Human Development Report 2004 (AHDR), som samlet set skulle beskrive levevilkårene, herunder også resultater om livskvalitet. Eksempelvis blev der spurgt ind til præferencer vedrørende livsstil, tilfredshed med livet i lokalområdet samt tilfredshed med livet generelt. I undersøgelsen udtrykte $93 \%$ af de adspurgte at være rimeligt tilfreds eller meget tilfreds med livet i det store og hele (SLiCA tabel 390).

\section{Livskvalitet i Sydgrønland}

De store befolkningsundersøgelser og rapporter, som SliCA og AHDR, kan give et overordnet og ganske omfattende indblik i levevilkår og livskvalitet i Arktis, men formår for det meste ikke at forklare, hvad der ligger bag de resultater, de præsenterer. Til det må man gå et lag dybere ned i den kvalitative forskning. I forbindelse med mit feltarbejde i Sydgrønland stod det klart, at tilfredsheden med livet afhang af en række sociale indikatorer, som primært havde med familie, arbejde og natur at gøre. Gennemsnitligt udtrykte samtlige interviewpersoner en generel tilfredshed med livet (spørgsmål 9 i interviewguiden) på 'over middel'. Der var ikke stor spredning på svarene generelt, men der var dog flere mænd end kvinder, der tillagde det offentlige velfærdssystem betydning for deres oplevede livskvalitet. Ifølge alle mænd var det offentlige velfærdssystem 'meget vigtigt' for, om de følte, at de havde et godt liv, mens det kun var to af kvinderne, der udtrykte det samme. De resterende svar fra kvinderne lå spredt fra 'under middel' til 'over middel'. 
Udover svarene på de forberedte spørgsmål, viste undersøgelsen, at det også betød noget for interviewpersonernes oplevede livskvalitet, hvor de fysisk boede. Især i Nanortalik blev der uopfordret udtrykt tanker om at flytte, eller at andre skulle flytte til byen, primært for at komme tættere på familie. I tre ud af de otte interviews fra byen blev der givet udtryk for, at tilfredsheden med livet ville være bedre, hvis de kunne flytte til Nuuk. På spørgsmålet om, hvad der skulle til for at blive meget tilfreds med livet, svarede en kvinde i starten af 30'erne fra Nanortalik for eksempel at, "Jeg vil ellers gerne flytte herfra. Ikke sådan hele livet, men måske prøve at flytte 1 til 2 år herfra. Men min koreste synes, det er vigtigt at bo her for ham". I samme by var der to interviews, hvor det omvendte var tilfældet. Tilfredsheden med livet ville være større, hvis venner og familie ville flytte tilbage til byen. I alle interviews fordelt på de to byer og to bygder i Sydgrønland, var flytning/vandring et gennemgående tema. Det havde en følelsesmæssig betydning for interviewpersonen, og blev uopfordret bragt ind i interviewsamtalen. En mand i slutningen af 20'erne fra Nanortalik berettede for eksempel: "Nu er der flyttet omkring 1200 mennesker fra Sydgrønland til Nuuk eller Danmark." og fastslog samtidigt: "Men jeg vil ikke flytte. Det vil jeg ikke!'. I sammendrag var holdningen, at enten blev man, hvor man var, fordi det var den livsform, man ønskede at fastholde, og derfor måtte man leve med et eventuelt savn af familie og venner. Eller også ventede man på at få mulighed for at flytte, og dermed potentielt bryde op med den vante livsform for at komme tættere på familie og venner, eller simpelthen fordi man ønskede en anden livsform.

Vandring ud af landet og mellem byer er et emne, der ofte tages op i samfundet, og som vedbliver at være aktuelt. I 2010 viste resultater fra Grønlands Selvstyres mobilitetsundersøgelse, at godt 40\% af befolkningen havde ønsker om at flytte indenfor 5 år. Til sammenligning var det i Danmark ${ }^{8} 34 \%$ af befolkningen, der flyttede mellem 2010 og 2015 (Danmarks Statistik 2016). Den grønlandske mobilitetsundersøgelse pegede endvidere på, at uddannelse og familie var blandt de vigtigste årsager til at flytte (Grønlands Selvstyre, 2010). Familie, det sociale netværk og tilfredshed med egen bolig, var samtidig de største årsager til ikke at flytte. Undersøgelsen er ikke siden fulgt op, men den seneste befolkningsfremskrivning fra Grønland Statistik viser, at folketallet er støt faldende og vil være det frem mod 2050 (Grønlands Statistik, 2019). Dette skyldes, ifølge fremskrivningen, færre fødsler og længere middellevealder, kombineret med den nuværende nettoudvandring.

\section{Naturens betydning for livskvaliteten}

Tidligere havde det grønlandske samfund en subsistensøkonomisk struktur. Subsistensøkonomi forbindes - især i den vestlige verden - med livsformer i fattige natursamfund, hvor husets produktion (som indebærer fangst, fiskeri og indsamling af planter og bær) er selve eksistensgrundlaget for husholdningen. I Grønland lever man ikke helt på denne

\footnotetext{
${ }^{8}$ som ifølge Danmarks Statistik er den befolkning der flytter næstmest i EU (Danmarks Statistik 2016)
} 
måde længere. Subsistensøkonomiske aktiviteter derimod, handler om mere end blot overlevelse; det handler også om åndelig og kulturel vitalitet. Det er almindeligt at kombinere lønnet arbejde med naturaktiviteter, såsom fangst og fiskeri, samt dele det med familie, venner og omgivelser (Poppel 2009, Rasmussen 2005, Hertz 1995). Denne blanding af markedsøkonomi og subsistensøkonomi/selvforsyningsøkonomi, hvis samfundsmæssige signifikans er bredt anerkendt (Hertz 1999, Rasmussen 2005, Poppel 2008, Poppel \& Kruse 2009, Hendriksen 2013), findes i alle byer og bygder ${ }^{9}$, og er en almindelig del af hverdagen for langt de fleste. Det er således en praksis, som i mange tilfælde udføres mere af lyst og vilje end af nød og manglende alternativer, og som derfor optræder på et slags kulturelt hobbyplan. Der er desuden studier, der viser, at lønnet arbejde kan være med til at opretholde en tilværelse med subsistensøkonomiske aktiviteter, fordi det ofte kræver en god økonomi at vedligeholde eksempelvis en båd og andet jagtudstyr (Poppel et. al 2017). Enten fanger og fisker man selv i husholdningen, eller også kender man nogen, der gør, som man enten får eller køber af. Der er derfor elementer, som man typisk finder i den selvstændige livsform; f.eks. Højrups begreb om den rurale solidaritet ${ }^{10}$ (Højrup 1989), der også optræder i lønarbejderlivsformen i Grønland, men som falder uden for det formelle økonomiske system. Dette blev ligeledes bekræftet i forbindelse med mit feltarbejde i Sydgrønland i foråret 2018. Her tilkendegav lidt over halvdelen af interviewpersonerne, at de som en almindelig del af hverdagen deltog i jagtaktiviteter uden selv at være fangere eller fiskere. Udover at være en del af hverdagen, var kontakten til naturen, som de fik gennem eksempelvis jagtaktiviteter, væsentlig for deres livskvalitet. Her er det iøjnefaldende, at samtlige mænd i undersøgelsen tilkendegav, at naturen var 'meget vigtig' for, om de følte, at de havde et godt liv, mens der var større spredning i svarene på det spørgsmål blandt kvinderne. Sammenlagt var det flertallet, der mente, at naturen var 'meget vigtig' for, om de følte, de havde et godt liv, og i helhed har naturens betydning for den oplevede livskvalitet den største score blandt svarene.

\section{Livskvalitet og selvstændighed}

Opsummerende viser resultaterne fra mit feltarbejde i Sydgrønland, at livskvalitet dér særligt handler om kultur, natur, familie og stedmæssig tilknytning. I en videre fortolkning kan man sige, at for interviewpersonerne handler livskvalitet i store træk om frihed. Deres frihed til at udøve en bestemt kultur, friheden til at være i naturen, friheden til at være sammen, og friheden til at vælge, hvor de vil bo. Værdien af frihed er også noget af det, der driver ønskerne om selvstændighed for Grønland, og det er der ikke noget mærkværdigt over. Frihed har nemlig en positiv indvirkning på vores individuelle livskvalitet. Et nærliggende eksempel er Danmark, som er blandt de frieste lande i verden, og som

\footnotetext{
${ }^{9}$ Som også gør sig gældende i Arktis generelt, se f.eks. Usher et.al (2002).

${ }^{10}$ Som kort fortalt handler om det at dele afgrøder mm. med hinanden i lokalsamfundene.
} 
ligger i toppen af den internationale lykke-måling i World Happiness Report (Helliwell, 2019; Helliwell 2018).

Ser man på sammenlignelige lande, der er blevet selvstændige i nyere tid, er der tendenser, der peger på, at øget frihed i form af national selvstændighed, på mange måder styrker behovet for at give udtryk for sin kultur og samhørigheden i befolkningen. I Norge og Island ser man befolkningen udøve deres nationalitet på flere måder, som kan have tilknytning til deres relativt nylige selvstændige status. Det er interessant at se på Norge og Island, fordi begge lande har haft tilhørsforhold til Danmark, og fordi de begge har fælles træk med Grønland i form af en relativt lille befolkning, særlige naturforhold og en vis afsondrethed fra andre lande. Derfor er det nærliggende at antage, at den kulturelle bevægelse, der har fundet sted i de to lande også vil kunne finde sted i Grønland, hvis man løsriver sig fra Rigsfællesskabet.

I Norge finder den kulturelle markering i høj grad sted gennem det at bære nationaldragter og ved at markere nationaldage (Eilertsen 2012, Goertzen 2007). I Island har man en meget udadvendt national profilering (Huijbens 2011) og man markerer tydeligt sin nation gennem sproget. I dag er det de færreste unge islændinge, der taler dansk, og de kommunikerer hellere på engelsk, hvis det ikke skal foregå på islandsk. Det er resultatet af en længere politisk indsats for at styrke det islandske sprog og på samme tid tage afstand fra det danske sprog (Vikør 2010).

Det er langt fra givet, at alle de kulturelle markeringer, man ser i Norge og Island har med selvstændighed at gøre, men det lader til, at den kulturelle vitalitet og samhørighed er styrket i de to lande efter deres løsrivelse. Dermed kan man også antage, at selvstændighed kan føre til, at den i forvejen stærke grønlandske kultur, bliver endnu mere markant i sit udtryk. Det åbner også op for en forestilling om, at livskvaliteten - i det omfang den er knyttet til følelsen af friheden til og behovet for at udøve sin kultur og at føle samhørighed gennem dette - vil blive øget, hvis Grønland bliver selvstændigt.

\section{Diskussion}

Artiklen her har forsøgt at give et indblik i nogle af de livsformer, der findes i Grønland, og hvordan de hænger sammen med livskvalitet. Det er langt fra en komplet livsformsanalyse, der er tale om, men der er fremhævet nogle væsentlige træk, som skiller sig ud i det eksisterende datamateriale og i den empiri, der er fremlagt.

I Grønland går livsformerne på tværs af teoriens skel

Når det kommer til husholdningsøkonomi og den måde folk foretrækker at leve på, har den grønlandske levevis nogle særlige træk, som går igen på tværs af den rurale og den urbane livsform. I en grønlandsk kontekst bliver livsformsanalysens økonomiske ver- 
densbillede dermed udfordret af den særlige blandede økonomi i Grønland, hvor markedsøkonomi kombineres med subsistensøkonomi/selvforsyningsøkonomi. Der er flere måder, hvorpå Højrups ideer om den rurale og urbane livsform ikke udfolder sig tilstrækkeligt, når det kommer til det grønlandske samfund. Der er ganske vist forskel på det tempo, man finder i en bygd og det, man finder i by, men der findes mange eksempler på kombinationer af rurale og urbane livsformer. Det skyldes, at det at flytte bosted er noget, man har praktiseret igennem årtusinder i Grønland. Derfor er der også mange, der bor i byer eller bygder, som ikke er født eller opvokset der, og selvom en del på et tidspunkt flytter tilbage, så er der også mange, der ikke gør. Det betyder, at Højrups forestilling om, at man ikke kan skifte livsform, ikke helt holder. De, der flytter fra bygd til by eller helt ud af landet, er nødt til at tilpasse deres livsform til livet dér.

Som nævnt $\mathrm{i}$ analysen, er der strengt taget kun tale om en egentlig bylivsform $\mathrm{i}$ Nuuk. Det er ikke bare fordi, at det kun er Nuuk, der tilbyder muligheder, der minder om andre store byer i Skandinavien. Det handler også om graden af anonymitet og den sociale dynamik. I de mindre byer, og især i bygderne, er der stort set ingen anonymitet. De fleste ved, hvem folk er, hvor de bor, og hvem de er i familie med. Det er en integreret del af den sociale dynamik på stedet, og derfor helt på linje med teorien om den rurale livsform. Men idealet om den rurale livsform finder man også udfoldet i Nuuk og de større byer. For eksempel når det kommer til kontakten til naturen, de traditionelle aktiviteter samt den søgen efter samhørighed og familiaritet, som tidligere eksemplificeret med navne og slægtskab. Det er også denne samhørighed og familiaritet, interviewpersonerne fra Sydgrønland kommer ind på, når de taler om, at de ønsker at flytte væk fra byen, eller når de ønsker familie og venner tæt på.

Selvom Nuuk med sine ca. 18.000 indbyggere i sammenligning med byer i Danmark er lille, og selvom byen har mange tilflyttere fra de mindre byer og bygder, er der naturligvis (lidt) længere mellem dem, man kender. Men byen er stadig ikke større, end at nogen altid er i relation med nogen, man kender - enten familiært, venskabeligt eller i arbejdsmæssig sammenhæng. Tanken om en opdelt rural og urban identitet er derfor udfordret, fordi livsformerne er mere socialt og kulturelt vævet ind i hinanden i en grønlandsk sammenhæng, end livsformsteorien formår at begribe.

\section{Selvstændighed kan få betydning for livskvalitet og livsformer}

For at diskutere livskvalitet i sammenhæng med selvstændighed, bliver vi nødt til at sætte livskvalitet i kontekst med noget, som vi kan antage, at en eventuel selvstændighed også vil påvirke. Hvordan vil selvstændighed f.eks. påvirke kulturen eller den stedmæssige tilknytning? I analysen kom det frem, at folketallet er faldende, og at der i fremtidens Grønland vil være endnu færre indbyggere; særligt børn og unge samt folk i den erhvervsaktive alder. Hvis man oveni dette forestiller sig, at flere vil udvandre eller f.eks. flytte til Nuuk, kan man spørge, hvad selvstændighed vil betyde for livsformerne, og dermed også 
livskvaliteten. Hvis der bliver færre til at opretholde erhvervslivet, hvis andelen af offentligt forsørgede ikke ændrer sig, og folk flytter fra yderområderne og ind i byerne, vil dette med al sandsynlighed sætte yderligere pres på velfærdssystemet. Samtidig kom det $i$ analysen frem, at livskvalitet for mange er knyttet til følelsen af frihed og at man ved at sammenligne med andre nordiske lande, der har opnået selvstændighed, kan argumentere for, at livskvaliteten vil blive øget, hvis Grønland bliver selvstændigt.

Økonomisk Råd har i deres rapporter og ved flere lejligheder påpeget, at såfremt selvstændighed træder i kraft uden en ændring i de økonomiske vilkår ${ }^{11}$, så vil levestandarden forringes. Man kan derfor også argumentere for, at selvstændighed vil påvirke den enkeltes oplevede livskvalitet i en negativ retning, hvis det betyder, at befolkningen stilles økonomisk ringere, og ikke kan opretholde en rimelig levestandard.

Nettoudvandringen fra Grønland har de seneste 30 år hvert eneste år været positiv. Det betyder, at fraflytningen har oversteget tilflytningen. Samtidig er antallet af bygdeboere siden begyndelsen af 0'erne faldet med ca. 3.000 indbyggere til godt 7.000 i 2019 (Statistikbanken). Begge dele kan man argumentere for, er en følge af den globale tendens til urbanisering. For Grønlands vedkommende kan man videre argumentere for, at denne tendens vil blive forstærket, hvis landet vælger at løsrive sig fra Rigsfællesskabet. Det skyldes, at der, som det ser ud lige nu, er en risiko for, at de økonomiske vilkår, som fremhævet af Økonomisk Råd, vil blive forringet, og at flere vil blive presset til at flytte til de større byer for at finde arbejde. Såfremt selvstændighed medfører en øget urbanisering, kan det få både negative og positive konsekvenser for livskvaliteten hos den grønlandske befolkning. Som det kom frem under mit feltarbejde, findes der de, som ikke ønsker at flytte, og for hvem det gode liv er knyttet til det sted, man bor. For disse, som allerede i dag oplever konsekvenserne af den øgede urbanisering, vil selvstændighed og øget urbanisering få en negativ indvirkning på den oplevede livskvalitet. De har svært ved at tilpasse sig og ved at klare sig godt $\mathrm{i}$ andre omgivelser. For dem er den medfødte livsform måske så essentiel, at de har svært ved at trives på andre måder eller andre steder. ${ }^{12}$ Men det er også væsentligt at holde sig for øje, at befolkningen - som tidligere nævnt - historisk har vist evne til at kombinere urbane og rurale livsformer i byen. Der er en vis fleksibilitet i de grønlandske livsformer; noget der ligeledes gør sig gældende for de mange, der flytter fra Grønland til Danmark. Det er en evne, der kan vise sig at være en styrke i befolkningens tilpasningsparathed over for store ændringer, som f.eks. selvstændighed.

\footnotetext{
${ }^{11}$ Udover at bloktilskuddet bortfalder.

${ }^{12}$ Artiklen her er ikke gået dybere ind i vandringernes sociale problematik i forhold til livsformer, men der ligger her et aktuelt emne, som kan skabe større afklaring i forhold til de tilpasningsproblemer der kan opstå i Grønland, når folk flytter fra et sted til et andet (og så vidt også i forhold til grønlandske livsformer i Danmark).
} 


\section{Konklusion}

Spørgsmålet om, hvordan livsform og livskvalitet hænger sammen, er i denne artikel forsøgt belyst med elementer fra livsformsanalysen, data fra eksisterende undersøgelser samt empirisk materiale fra mit feltarbejde i Sydgrønland. Artiklen peger på, at man har en mere selvstændig livsform i bygderne og yderområderne, som er i tråd med teorien om en rural livsform og identitet. Det fremgår af artiklen, at særligt naturen har en væsentlig betydning for den generelle tilfredshed med livet, hvilket også underbygger eksisterende teori og forskning om sociale indikatorer i Arktis. Der er endvidere parametre, som har en betydning for livskvaliteten, og som er naturligt forbundet med livsformerne. Det er ud over tilknytningen til naturen - den sociale sammenhængskraft, som rummer mange forskellige facetter. Sidstnævnte, viser artiklen, bliver problematisk, når folk flytter fra sted til sted, og her er således grundlag for en videre og mere tilbundsgående forskning, som kan belyse vandringernes sociale problematikker, både indenfor landets grænser og i forhold til vandringer mellem Grønland og Danmark. Om der er en sammenhæng mellem det, vi i dag ved om livsformer og livskvalitet og udviklingen mod selvstændighed i Grønland, er svært at sige noget præcist om. Det grønlandske folk er tilpasningsdygtigt, og har fundet måder, hvorpå de kan kombinere rurale og urbane livsformer, men der er også faktorer, man ikke lige med ét kan ændre, som f.eks. uddannelsesgraden og den økonomiske situation. Med den viden vi har nu, må man overveje, hvad der bør komme i første række; selvstændighed eller et styrket folk og en bæredygtig økonomi. Det er ikke sikkert, det ene udelukker det andet, og det eneste man formentlig med sikkerhed kan sige er, at historien indtil videre har vist, at der ikke er negative konsekvenser forbundet med en sund økonomi eller en veluddannet befolkning. 
Litteratur

AHDR (2004). Arctic Human Development Report. Akuyeri: Stefansson Arctic Institute AHDR II (2015). Arctic Human Development Report: Regional Processes and Global Linkages. Copenhagen: Nordisk Ministerråd. http://dx.doi.org/10.6027/TN20145673

Andersen, T. \& Poppel, B. (2002). Living conditions in the Arctic. I: M.R. Hagerty, J. Vogel, \& V. Møller (red.), Assessing quality of life and living conditions to guide national policy. The state of the art [Social Indicators Research Series, vol. 11]. Dordrecht/Boston/London: Kluwer Academic Publishers. https://doi.org/10.1007/0-306-47513-8_10

Creswell, J.W. (2013). Research Design: Qualitative, Quantitative and Mixed Method Approaches. Sage Publications.

Danmark Statistik (2016). Hvor meget flytter danskerne? Tilgængelig på: https://www.dst.dk/da/informationsservice/blog/2016/02/hvor-meget-flytter-danskerne [Tilgået d. 28. maj 2019].

Eilertsen, L. (2012, October). Freedom Loving Northerners: Norwegian Independence As Narrated in Three National Museums. I: Great Narratives of the Past Traditions and Revisions in National Museums: Conference Proceedings from EuNaMus; European National Museums: Identity Politics; the Uses of the Past and the European Citizen; Paris 28 June-1 July \& 25-26 November 2011 (No. 078). Linköping: Linköping University Electronic Press, s. 179-216.

From, A., Jensen, K.J., Friis, P., Kjær, A. (1975). Levevilkår og Sociale Problemer i Vestgrønland. København: Socialforskningsinstituttet. Publikation 64.

Goertzen, C. (2007). Fiddling for Norway: revival and identity. Chicago: University of Chicago Press.

Grønlands Selvstyre (2010). Mobilitet i Grønland. Sammenfatning af hovedpunkter fra analysen af mobiliteten i Grønland. Mobilitetsstyregruppen, Nuuk 2010.

Grønlands Statistik (1994). Kalaallit Nunaanni Inooriaaseq/Levevilkår i Grønland. Den grønlandske levevilkårsundersøgelse, rapport fra undersøgelse af befolkningens økonomiske og materielle levevilkår. Nuuk, Grønland.

Grønlands Statistik (2016a). Erhvervsstruktur 2012-2016. Tabel: Antal virksomheder efter driftsform samt procentandel af lønsum, 2012-2016. Tilgængelig på: bank.stat.gl/esd2a [Tilgået d. 28. maj 2019].

Grønlands Statistik, 2016b. Tabel: Hovedbeskæftigelse efter tid, branche, distrikt og opgørelsesvariabel. Tilgængelig på: http://bank.stat.gl/api/v1/da/Greenland/AR/AR 30/ARXBFB4.px [Tilgået d. 28. maj 2019].

Grønlands Statistik (2016c). Tabel: Befolkningen i distrikterne efter tid og område. Tilgængelig på: http://bank.stat.gl/api/v1/da/Greenland/BE/BE01/BE0120/BEXST3 .PX [Tilgået d. 28. maj 2019]. 
Grønlands Statistik (2016d). Tabel Offentlig hjælp efter tid, distrikt, ydelser og enhed. Tilgængelig på: http://bank.stat.gl/api/v1/da/Greenland/SO/SO20/SOX008.px [Tilgået d. 28. maj 2019].

Grønlands Statistik (2016d). Tabel: Hovedbeskæftigelse og beskæftigelsesgrad efter tid, distrikt og opgørelsesvariabel. Tilgængelig på: http://bank.stat.gl/api/v1/da/Green land/AR/AR30/ARXBFB6.px [Tilgået d. 28. maj 2019].

Grønlands Statistik, 2019. Befolkningsfremskrivningen 2018-2028 (2050). Tilgængelig på: http://www.stat.gl/publ/da/BE/201804/pdf/Befolkningsfremskrivningen $\% 20$ 2018-2028\%20(2050).pdf [Tilgået d. 28. maj 2019].

Helliwell, J. F., Layard, R., \& Sachs, J. (2019). World Happiness Report 2019. New York: Sustainable Development Solutions Network.

Helliwell, J. F., Layard, R., \& Sachs, J. (2017). World Happiness Report 2018. New York: Sustainable Development Solutions Network.

Hendriksen, K. (2013). Grønlands bygder: økonomi og udviklingsdynamik. Ph.d.-afhandling. Aalborg Universitet, Institut for Planlægning og Danmarks Tekniske Universitet, DTU Management samt Center for Arktisk Teknologi, DTU Byg

Hertz, O. (1995). Økologi og levevilkår i Arktis - Uummannamiut. Christian Ejler's Forlag og Mellemfolkeligt Samvirke.

Huijbens, E.H. (2011). Nation Branding. A Critical Evaluation. Assessing the Image Building of Iceland. I: Isleifsson, Sumarlidi R. og Chartier, Daniel (eds.) Iceland and Images of the North. Québec: Presses de l'Université du Québec

Højrup, T. (1989). Det glemte folk: Llvsformer og centraldirigering. 4. oplag. Institut for Europæisk Folkelivsforskning, Statens Byggeforskningsinstitut.

Larsen, C.V.L., Hansen. C.B.H, Ingemann, C., Jørgensen, M.A., Olesen, I., Sørensen, I.K., Koch, A., Backer, V., Bjerregaard, P. (2019). Befolkningsundersøgelsen $i$ Grønland 2018 - Levevilkår, livsstil og helbred. Oversigt over indikatorer for folkesundheden. SIF's Grønlandsskrifter nr. 30, Statens Institut for Folkesundhed, SDU.

Larsen, J. N, Schweitzer, P. \& Fondahl, G. (eds.) (2010) Arctic Social Indicators - A follow up to the Arctic Human Development Report. København: Nordisk Ministerråd. http://dx.doi.org/10.6027/tn2010-519

Liao P.S. (2014) Perceived Quality of Life. I: Michalos A.C. (eds.) Encyclopedia of Quality of Life and Well-Being Research. Springer, Dordrecht. https://doi.org/10.1007/978-94-007-0753-5_2129

Poppel, B., Kruse J., Duhaime G., Abryutina L. (2007). SLiCA Results. Anchorage: Institute of Social and Economic Research, University of Alaska Anchorage.

Poppel, B. (2008). Er subsistensaktiviteter i Arktis en del af den markedsøkonomiske virkelighed eller er markedsøkonomien en del af en subsistensbaseret blandingsøkonomi? I: Grønlandsk kultur- og samfundsforskning 2006-2007. Nuuk: Forlaget Atuagkat, s. 217-232. 
Poppel, B. \& Kruse, J. (2009). The importance of a mixed cash- and harvest herding based economy to living in the Arctic - an analysis based on Survey of Living Conditions in the Arctic (SLiCA). I: V. Møller \& D. Huscka (eds.): Quality of Life in the New Millenium: Advances in Quality-of-Life Studies, Theory and Research. Social Indicators Research Series. Springer Verlag, Social Indicators Research Series, vol. 35, s. 27-42. https://doi.org/10.1007/978-1-4020-8569-7

Poppel, B., Fægteborg, M., Siegstad, M. O., \& Snyder, H. T. (2015). The Arctic as a 'Hotspot'for Natural Resource Extraction and Global Warming. The Economy of the North, s. 129-135.

Rasmussen, R. O. (2005). Analyse af fangererhvervet $i$ Grønland. Roskilde: Roskilde Universitet.

Reimer, G. A. (2010). Slægtskab og køn i grønlandske bysamfund - følelser af forbundethed. Phd-afhandling.

Reimer, G. A. (2012). Navn og navngivning - en grønlandsk identitetsmarkør. I: O. Høiris \& O. Marquardt (red.), Fra vild til verdensborger: Grønlandsk identitet fra kolonitiden til nutidens globalitet. Aarhus Universitetsforlag.

SLiCA (2007). Tabel 390. Tilgængelig på: https://iseralaska.org/static/living_conditions/images/SLICA_Results_Tables.pdf [Tilgået d. 28. maj 2019].

Skydsbjerg, H. (1999). Grønland - 20 år med hjemmestyre. Nuuk: Forlaget Atuagkat.

Statistikbanken. Tilgængelig på: http://bank.stat.gl/pxweb/da/Greenland/

Usher, P. J., Duhaime, G., \& Searles, E. (2003). The household as an economic unit in Arctic Aboriginal communities, and its measurement by means of a comprehensive survey. Social Indicators Research, årg. 61(2), s. 175-202. https://doi.org/10.1023/a:1021344707027

Veenhoven, R. (2005). Apparent Quality-of-Life in Nations: How Long and Happy People Live. Social Indicators Research, årg. 71, s. 61-86. https://doi.org/10.1007/s11205-004-8014-2

Veenhoven, R. (2014). Individual Quality of Life. I: Michalos A.C. (eds), Encyclopedia of Quality of Life and Well-Being Research. Springer, Dordrecht

Vikør, L. S. (2010). Language purism in the Nordic countries. International Journal of the Sociology of Language, årg. 2010(204), s. 9-30. https://doi.org/10.1515/ijs1.2010.028 